\title{
5-Azacitidine Induces Cell Death in a Tissue Culture of Brachypodium distachyon
}

\author{
Alexander Betekhtin ${ }^{1, *(1)}$, Anna Milewska-Hendel ${ }^{2}$, Lukasz Chajec ${ }^{3}$, Magdalena Rojek ${ }^{1}$, \\ Katarzyna Nowak ${ }^{4}$, Jolanta Kwasniewska ${ }^{1}$, Elzbieta Wolny ${ }^{1}$, Ewa Kurczynska ${ }^{2}$ and \\ Robert Hasterok 1 \\ 1 Department of Plant Anatomy and Cytology, Faculty of Biology and Environmental Protection, \\ University of Silesia in Katowice, 40-032 Katowice, Poland; magdalena.rojek@us.edu.pl (M.R.); \\ jolanta.kwasniewska@us.edu.pl (J.K.); elzbieta.wolny@us.edu.pl (E.W.); robert.hasterok@us.edu.pl (R.H.) \\ 2 Department of Cell Biology, Faculty of Biology and Environmental Protection, \\ University of Silesia in Katowice, 40-032 Katowice, Poland; anna.milewska@us.edu.pl (A.M.-H.); \\ ewa.kurczynska@us.edu.pl (E.K.) \\ 3 Department of Animal Histology and Embryology, Faculty of Biology and Environmental Protection, \\ University of Silesia in Katowice, 40-032 Katowice, Poland; lukasz.chajec@us.edu.pl \\ 4 Department of Genetics, Faculty of Biology and Environmental Protection, University of Silesia in Katowice, \\ 40-032 Katowice, Poland; katarzyna.nowak@us.edu.pl \\ * Correspondence: alexander.betekhtin@us.edu.pl; Tel.: +48-32-2009-484
}

Received: 24 April 2018; Accepted: 12 June 2018; Published: 19 June 2018

\begin{abstract}
Morphological and histological observations revealed that, at a concentration of $50 \mu \mathrm{M}$, 5 -azacitidine (5-azaC) totally inhibited the induction of embryogenic masses (EM), while the cultivation of explants (zygotic embryos; ZEs) in the presence of $5 \mu \mathrm{M}$ of 5-azaC led to the formation of a callus with EM in 10\% of the cases. Transmission electron microscopy (TEM) analyzes revealed the presence of the morphological and ultrastructural features that are typical for the vacuolar type of cell death in the callus cells that were treated. A TUNEL assay confirmed the presence of DNA double-strand breaks for the callus cells that had been treated with both 5 and $50 \mu \mathrm{M} 5$-azaC concentrations. Analysis of the gene expression of selected cell death markers demonstrated a reduced expression of metacaspase, protein executer 1 (EX1), and thioredoxin (TRX) in the callus cells that had been treated compared to the control culture. The strongest increase in the gene activity was characteristic for glutathione S-transferase (GST). Our studies also included an analysis of the distribution of some arabinogalactan proteins (AGPs) and extensin epitopes, which can be used as markers of cells that are undergoing death in a Brachypodium distachyon tissue culture.
\end{abstract}

Keywords: Brachypodium; 5-azacitidine; cell death; tissue culture

\section{Introduction}

Brachypodium distachyon (Brachypodium) has become a useful model system to study various aspects of a tissue culture in grasses. To date, it has been used to analyze the chemical composition of the cell wall of different organs, tissues, and cell types at different stages of development [1,2]; the functions of different genes [3]; and the genetic regulation of somatic embryogenesis (SE) in grass species [4].

Plant cells that are introduced into a tissue culture undergo successive changes, which include dedifferentiation, the acquisition of pluripotency or totipotency, the proliferation of cells, differentiation, and finally the formation of embryos [5]. DNA methylation plays a pivotal role during the processes of dedifferentiation/differentiation and in the formation of the embryogenic masses. This DNA 
modification regulates gene activity in a positive or negative manner [6]. Although in most cases it causes gene inactivation $[7,8]$, it has also been demonstrated that the methylation of individual genes may also induce their expression [9]. The DNA-hypomethylating agent, 5-azacitidine (5-azaC), is often used to reveal the functions of DNA dynamics. Yamamoto et al. [10] showed that the inhibition of DNA methylation by 5 -azaC in a carrot culture impeded the formation of embryogenic cell clumps from the carrot epidermal cells. The impact of DNA methylation on somatic embryogenesis (SE) in Arabidopsis thaliana (Arabidopsis) demonstrated a decrease in the global DNA methylation level during SE that accompanied with the upregulation of DNA methylases and the downregulation of DNA demethylases [11]. These authors revealed significant repression of $L E C 2, L E C 1$, and $B B M$ in vitro under the treatment of 5-azaC. As a consequence, this culture was incapable for SE induction. The research on Theobroma cacao demonstrated that the long-term SE induced the decline in embryogenic potential, which can be reversible by the addition of 5-azaC [11]. The experimental changes in the total DNA methylation level may play a critical role in the different processes of plant development. For example, treatment of cold-sensitive Arabidopsis plants with 5-azaC makes the process of vernalisation unnecessary [12]. It was demonstrated for barley coleoptiles that at a concentration of $100 \mu \mathrm{g} / \mathrm{mL}$, 5-azaC may have an effect on the stimulation of DNA fragmentation [13]. Transcriptome analyzes of Arabidopsis seedlings treated with either 5 -azaC or zebularine revealed a significant number of upregulated genes especially linked with transposable element genes. This showed that these two agents have a disproportionately large influence on the loci that are silenced by DNA methylation [14].

DNA cleavage and the expression of specific genes-for example genes encoding for metacaspase, glutathione S-transferase, and protein executer 1-are specific features of programmed cell death [15-18]. This process is also characterized by the activation of endonucleases, which produce single-strand breaks and cause low molecular weight DNA (mono- and oligonucleosomes) fragments to be formed [15]. One of the methods that has been described to identify this process is TdT-mediated dUTP nick end labelling, which is known as a TUNEL assay [19].

Hydroxyproline-rich glycoproteins (HRGPs) are important plant cell wall components that are involved in many aspects of plant growth and development, including the responses to stress [20,21]. The HRGP superfamily comprises a continuum of molecules from the nonglycosylated/minimally glycosylated proline-rich proteins (PRPs) to the moderately glycosylated extensins to the highly glycosylated AGPs (for review, see [22,23]). Based on literature data, it is hypothesized that AGPs and extensins may be involved in the cell death process [24].

The aim of this study was to determine the effects of 5-azaC during the formation of the embryogenic masses as well as to characterize the morphology, histology, ultrastructure, and chemical composition of selected components of the cell wall. The expression of selected genes in both the experimental (treated with 5-azaC) and control explants was also determined.

\section{Results}

\subsection{Morphological, Histological, Cytological, and Ultrastructural Observations in the Brachypodium Callus}

In a previous work, we demonstrated that the embryogenic callus of Brachypodium can be successfully obtained from immature embryos [2]. The results presented here show that after a week of cultivation on a callus induction medium (CIM), neither the explants in the control conditions with a developing callus nor those that had been grown in the presence of 5 and $50 \mu \mathrm{M}$ of 5 -azaC displayed any morphological differences. These, however, became clearly visible after three weeks of cultivation (Figure 1a-c). The Brachypodium embryogenic callus of the control explants (Figure 1a,d) and the explants that had been treated with $5 \mu \mathrm{M}$ of 5 -azaC (Figure 1b,e) were primarily composed of two different types of callus areas: (i) one that is vitreous and friable, which contained parenchymatous cells (PC) and (ii) a compact callus that was represented by embryogenic masses (EM) that were yellowish in color. After 21 days of cultivation, $70 \%$ of the control callus and $10 \%$ of callus grown in the presence of $5 \mu \mathrm{M} 5$-azaC had formed EM (Figure 1g). The treatment with $50 \mu \mathrm{M}$ of 5-azaC led 
only to the formation of a non-embryogenic callus, which was composed of a PC with no visible EM (Figure 1c,f). The histological sections clearly demonstrated that apart from normal embryogenic cells, highly vacuolated PC were also present (Figure 1d-f).
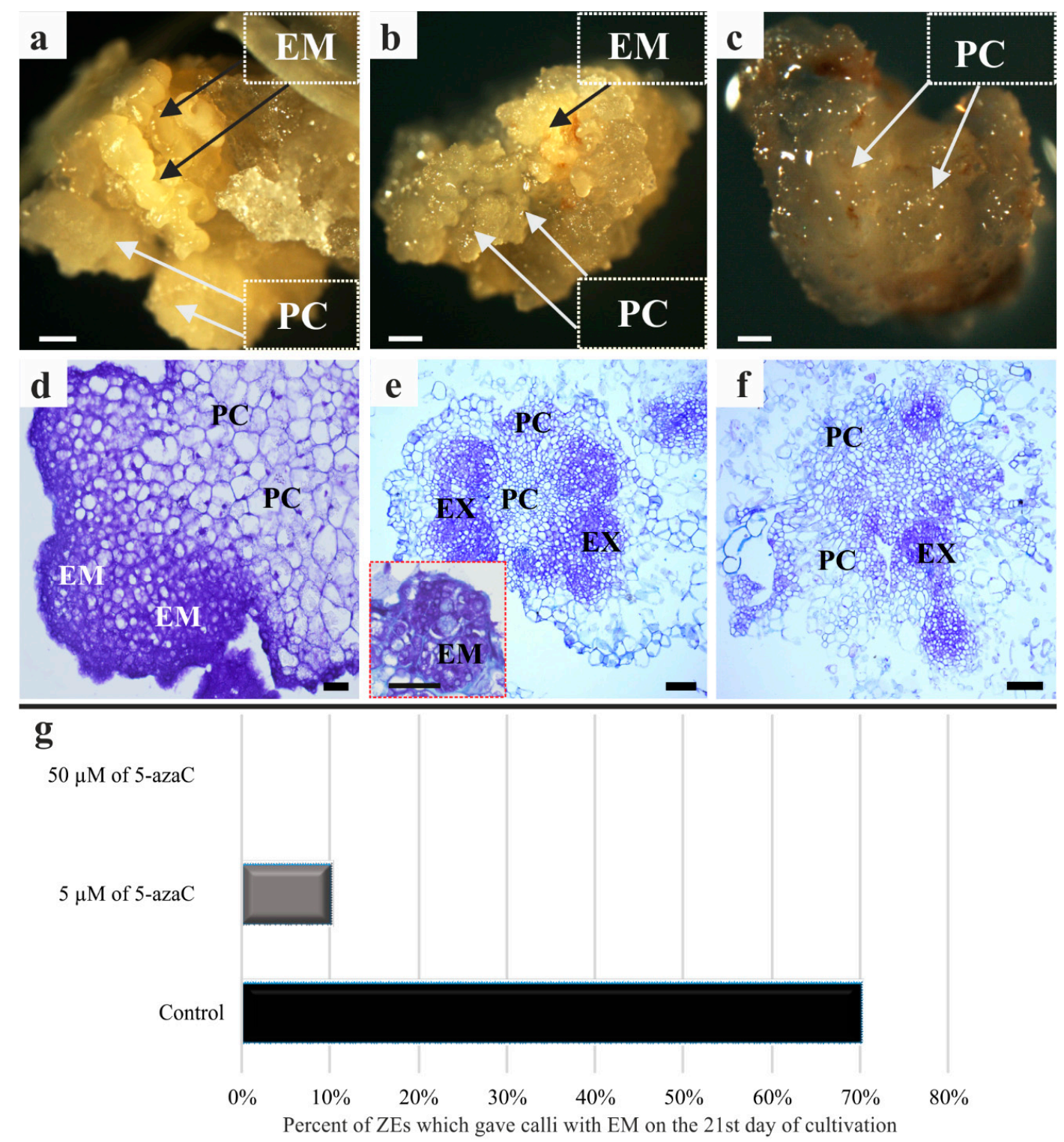

Figure 1. Morphology $(\mathbf{a}-\mathbf{c})$ and histology $(\mathbf{d}-\mathbf{f})$ of the Brachypodium callus. (a,d) Control callus; $(\mathbf{b}, \mathbf{e})$ callus that has been treated with $5 \mu \mathrm{M}$ of 5-azaC, (inset figure on (e) demonstrated embryogenic masses (EM)) and (c,f) callus that has been treated with $50 \mu \mathrm{M}$ of 5-azaC (black arrows: EM; white arrows; parenchymatous cells: PC; cells of an explant: EX). (g) frequency of ZEs which gave calli with EM on the 21st day of cultivation. Scale bars, (a-c) $200 \mu \mathrm{m}$; (d) $20 \mu \mathrm{m} ;(\mathbf{e}, \mathbf{f}) 100 \mu \mathrm{m}$.

Transmission electron microscopy (TEM) analysis revealed that regardless of the duration of the culture, the cytoplasm of the explant cells of the control callus was electron dense and numerous organelles such as a prominent nucleus (N) with a nucleolus (NU), mitochondria (M), plastids with numerous starch grains (S), an endoplasmic reticulum (ER), and small vacuoles (V) were clearly visible (Figure 2a,b). The plastids $(\mathrm{P})$ with starch $(\mathrm{S})$ were located in the vicinity of the nucleus and the cytoplasm contained numerous ribosomes. The cells were characterized by the presence of thin cell walls, which may indicate that cytokinesis occurred during the cultivation of the tissue culture. 

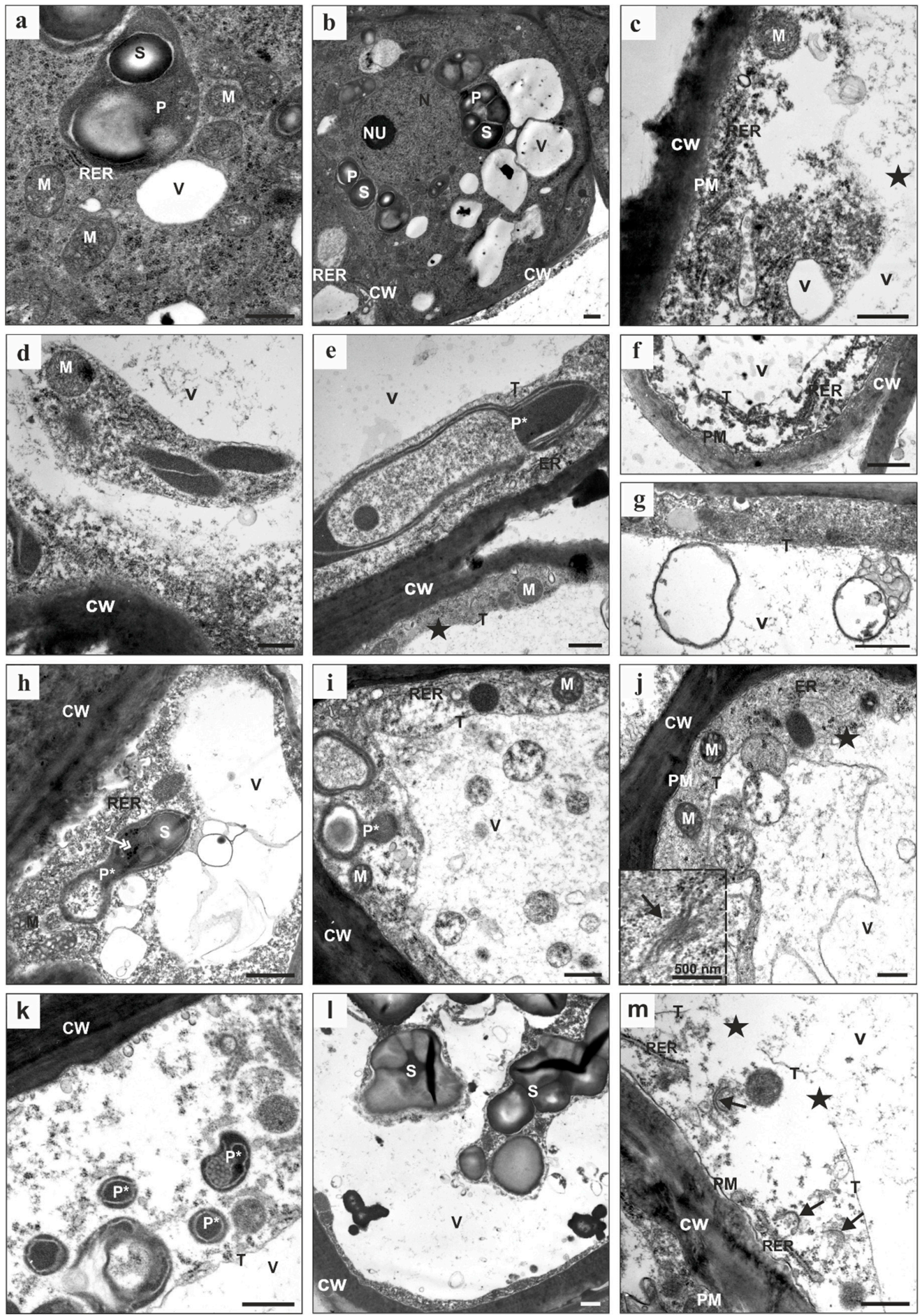

Figure 2. Callus cell ultrastructure in the control $(\mathbf{a}, \mathbf{b})$ and in the callus that has been treated with $5 \mu \mathrm{M}(\mathbf{c}-\mathbf{f})$ and $50 \mu \mathrm{M}(\mathbf{g}-\mathbf{m})$ of 5-azaC. CW: cell wall; ER: endoplasmic reticulum; M: mitochondria; $\mathrm{N}$ : nucleus; NU: nucleolus; P: plastid; $\mathrm{P}^{*}$ : plastid with an altered ultrastructure; PM: plasma membrane; RER: rough endoplasmic reticulum; S: starch; T: tonoplast; V: vacuole; arrows: dictyosomes of Golgi apparatus; double arrow: plastoglobules; asterisks: tonoplast breakdown. Scale bars, $1 \mu \mathrm{m}$. 
In the cells from the callus that had been treated with 5-azaC, similar and prominent changes in the cytoplasm of the parenchymatous cells were detected regardless of the concentration of this hypomethylating agent or the duration of the culture (Figure 2c-m). These included the fragmentation of the ER followed by the total disintegration of this organelle. Disintegration was also observed in the case of the dictyosomes of the Golgi apparatus (GA; Figure 2m, arrows). Both the ER cisterns and the GA dictyosomes became less pronounced and had no well-defined shape, which may indicate that their membranes were disintegrating (Figure 2j; inset). Prominent changes in the plastid ultrastructure were also evident (Figure 2e,h,i,k,l). Large and numerous starch grains were present in the amyloplasts. The density of the plastid stroma and the number of plastoglobuli increased (Figure $2 \mathrm{~h}$, double arrow), which was accompanied by the disintegration of the internal membrane (Figure 2e,k). The plastids that were fused to the vacuole appeared to rupture and this process was associated with the degradation of their outer membrane (Figure 2j,1). They disintegrated much earlier compared to the mitochondria, which were preserved for the longest period of time compared to the other organelles (Figure 2c,e,i). Although the collapse of the tonoplast was the most prominent feature in all of the cells that were investigated (Figure 2c,j,m; asterisk), the progress of the interruption of the tonoplast membrane was gradual. Numerous membrane-bound bodies with remnants of the cytoplasm present in most of them were observed inside the vacuolar compartments (Figure $2 g, i, j$ ). The plasma membrane was intact almost until the end of cell death. As cell death proceeded, the cytoplasm narrowed (Figure 2e,l), was located around the periphery of a cell, and became more translucent (Figure $2 \mathrm{c}, \mathrm{k}, \mathrm{m}$ ). Numerous electron-lucent areas were detected within the cytoplasm. Inside the area of the former vacuole granular material, parts of the cytoplasm with plastids and other organelles in a state of decay were present (Figure 2d,1). In general, during cell death, the tonoplast disruption preceded the breakdown of the plasma membrane and it appears that the collapse of the tonoplast is the main executor of cell death.

Application of the TUNEL assay permitted the DNA fragmentation in the Brachypodium callus nuclei to be visualized. Although this fragmentation was detected in the control callus cells and the callus cells that had been treated with 5 or $50 \mu \mathrm{M}$ of 5-azaC (Figure 3), only weak fluorescence was observed in the control cells, whereas strong FITC signals were observed in the callus cells that had been treated with the hypomethylating agent. The frequencies of labelled nuclei did not change during the 21 days of the in vitro culture. TUNEL-specific fluorescence was not observed in the negative control (no terminal transferase was used; Figure $3 b, b^{\prime}$ ), whereas all of the nuclei were labeled in the positive control (Figure $3 c, c^{\prime}$ ). No differences in the frequencies of the TUNEL-positive nuclei were observed on the 7th, 14th, and 21st days of the culture (Figure 3; only the results for the 14th day of the in vitro culture are shown). 

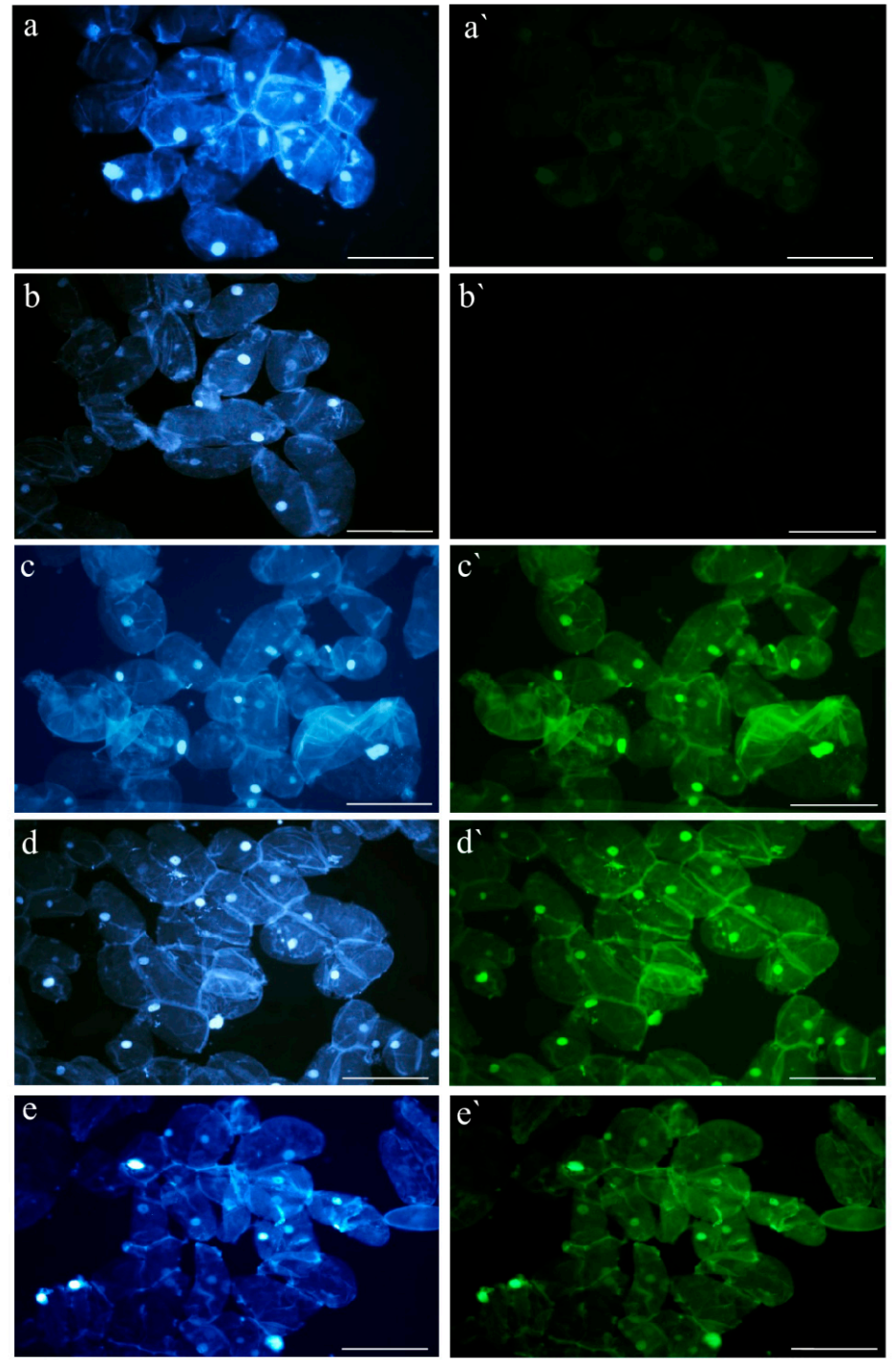

Figure 3. In situ detection of DNA fragmentation in the Brachypodium callus cells on the 14th day of the culture using the TUNEL assay. Blue fluorescence: DAPI staining $(\mathbf{a}-\mathbf{e})$, green fluorescence: FITC marking TUNEL-positive nuclei $\left(\mathbf{a}^{\prime}-\mathbf{e}^{\prime}\right)$. $\left(\mathbf{a}, \mathbf{a}^{\prime}\right)$ control callus; $\left(\mathbf{b}, \mathbf{b}^{\prime}\right)$ negative control in TUNEL reaction; $\left(\mathbf{c}, \mathbf{c}^{\prime}\right)$ positive control in TUNEL reaction; $\left(\mathbf{d}, \mathbf{d}^{\prime}\right)$ callus that has been treated with $5 \mu \mathrm{M}$ of 5 -azaC; $\left(\mathbf{e}, \mathbf{e}^{\prime}\right)$ callus that has been treated with $50 \mu \mathrm{M}$ of 5-azaC. Scale bars, $50 \mu \mathrm{m}$.

\subsection{RT-PCR}

Complementary DNAs (cDNAs) were used as templates for the PCR amplification with the appropriate primers (Table 1). In order to test the hypothesis of whether 5-azaC-induced cell death is programmed or not, 12 genes were assessed. Almost all of them were characterized by a decrease in their expression after treatment with this hypomethylating agent. The lowest expression levels, whose values were significantly different that the control in the culture that had been treated with 5 and $50 \mu \mathrm{M}$ of 5-azaC, were these for the genes Bradi1g60756.1, Bradi3g29270 and Bradi5g09650.1, which encode for metacaspase, protein executer 1 (EX1) and thioredoxin (TRX), respectively (Figure 4a). Values that were significantly different between only the 5 and $50 \mu \mathrm{M}$ of the 5-azaC-treated cultures were demonstrated for the genes Bradi1g60756.1 (metacaspase) and Bradi2g18877.1 (hexokinase). The strongest increase in gene activity was characteristic for Bradi3g35620.1, which encodes for glutathione S-transferase (GST) and it was up to 300- and 1000-fold higher for the 5 and $50 \mu \mathrm{M} 5$-azaC-treated cultures, respectively (Figure 4 b). 
Table 1. Oligonucleotide primers used for RT-PCR reaction with the relevant description of the genes.

\begin{tabular}{|c|c|c|}
\hline Genes & Description of the Genes & Primer Sequence $\left(5^{\prime}-3^{\prime}\right)$ \\
\hline AK437296 & ubiquitine & $\begin{array}{l}\text { pF-GAGGGTGGACTCCTTTTGGA } \\
\text { pR-TCCACACTCCACTTGGTGCT }\end{array}$ \\
\hline Bradi3g01470.1 & aminoacylase activity, catalase activity & $\begin{array}{l}\text { pF-TTGTGAAGAGGTTCGCGGATGC } \\
\text { pR-TCCCACACGACTTATCACACTGG }\end{array}$ \\
\hline Bradi3g35620.1 & putative glutathione S-transferase & $\begin{array}{l}\text { pF-TTTCCATTGCTGAGCACAAGAGC } \\
\text { pR-GGGACTTGACCAAATGGATTGCG }\end{array}$ \\
\hline Bradi5g09650.1 & thioredoxin peroxidase activity & $\begin{array}{l}\text { pF-GAACCCTTCAGGCCCTGCAATATG } \\
\text { pR-AACCTGCTGGGCAAACCTCATC }\end{array}$ \\
\hline Bradi2g18877.1 & hexokinase & $\begin{array}{l}\text { pF-AATGACACGGTAGGCGAGGATG } \\
\text { pR-GACTTTCATATCGAGACCCTGACG }\end{array}$ \\
\hline Bradi2g18290.1 & $\begin{array}{l}\text { single-stranded DNA specific } 5^{\prime}-3^{\prime} \\
\text { exodeoxyribonuclease activity }\end{array}$ & $\begin{array}{l}\text { pF-AGGCACCTTGTGAAGCAGAAGC } \\
\text { pR-TCTGATGCGACAGCATACACCTTG }\end{array}$ \\
\hline Bradi1g75270.1 & pheophorbide oxygenase (PAO, ACD1) & $\begin{array}{l}\text { pF-ACCGTCCTTTCAAAGCGTGAGATG } \\
\text { pR-CGCTCCTTTGCAAGACGAACAC }\end{array}$ \\
\hline Bradi1g60762.1 & $\begin{array}{l}\text { metacaspase involved in regulation } \\
\text { of apoptosis }\end{array}$ & $\begin{array}{l}\text { pF-ACTGCATCCTCATCCTCACAGAG } \\
\text { pR-AGCCAGCAGATTCTCCTTCGTC }\end{array}$ \\
\hline Bradi1g60756.1 & $\begin{array}{l}\text { metacaspase involved in regulation } \\
\text { of apoptosis }\end{array}$ & $\begin{array}{l}\text { pF-ACTGCATCCTCACCCTTACACC } \\
\text { pR-AGAAGTGGAACACCAGGGAGTC }\end{array}$ \\
\hline Bradi1g05570.1 & BAX inhibitor related & $\begin{array}{l}\text { pF-ACGCCATCGTCCTGATGTTGTTC } \\
\text { pR-TGAGGAAGGCCGAGAAGATGAGC }\end{array}$ \\
\hline Bradi1g02697.1 & $\begin{array}{c}\text { XP-G/RAD2 DNA repair } \\
\text { endonuclease family }\end{array}$ & $\begin{array}{c}\text { pF-AGGGTTTGACGAAGCTGCTG } \\
\text { pR-TCCTTTCCTTCCTACCACAACCAG }\end{array}$ \\
\hline Bradi3g01470.2 & aminoacylase activity, catalase activity & $\begin{array}{l}\text { pF-AGGTGATGGACCCAGATGAG } \\
\text { pR-GAAGTTGTCCACGTTTCGGT }\end{array}$ \\
\hline Bradi3g29270.1 & protein executer 1 & $\begin{array}{l}\text { pF-GTTGGTGGCAACAGGAAACT } \\
\text { pR-GAATTCGGCTGAAGTGGGTA }\end{array}$ \\
\hline
\end{tabular}
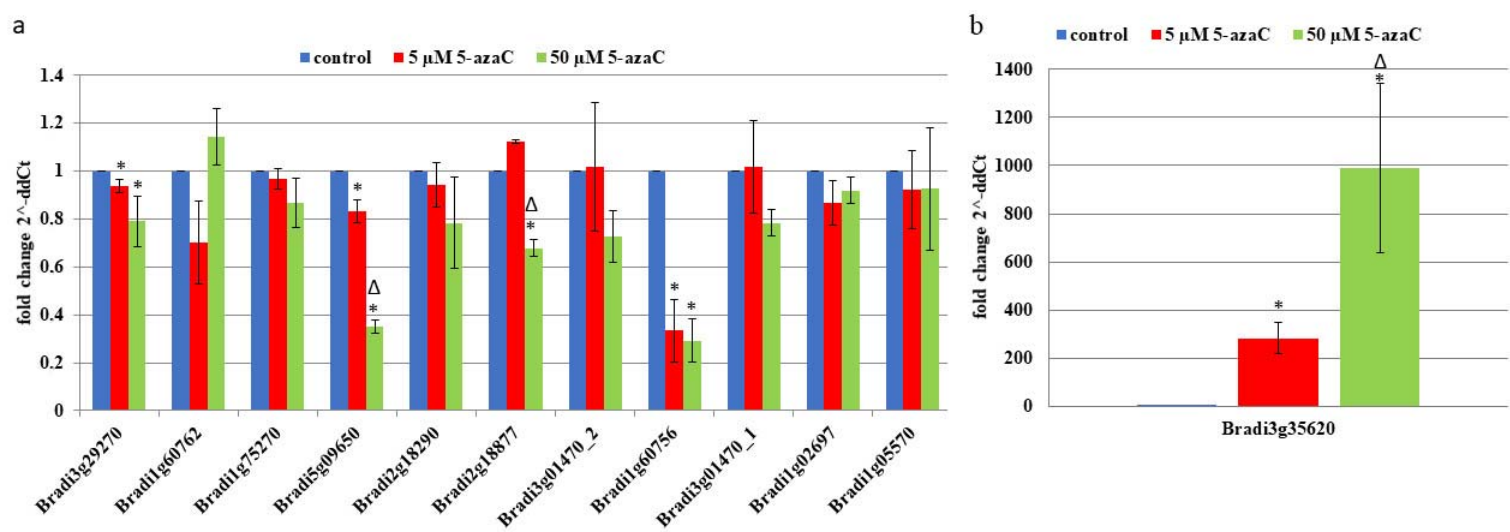

Figure 4. Relative expression levels of the selected PCD-related genes (a), in the explants that were cultivated on the CIM medium supplemented with 5 and $50 \mu \mathrm{M}$ of 5 -azaC (b). Relative expression levels were normalized to an internal control (AK437296, gene encoding for ubiquitin) and calibrated to the control culture (CIM medium with no 5-azaC). *: value is significantly different from the control culture $(p<0.05 ; n=3 \pm \mathrm{SD}), \Delta$ : value is significantly different from the $5 \mu \mathrm{M}$ of 5 -azaC-treated culture $(p<0.05 ; n=3 \pm \mathrm{SD})$.

\subsection{AGPs and Extensins under Different 5-azaC Treatments}

To test whether the selected AGP and extensin epitopes correlated with the cytological/ ultrastructural changes that accompany the cell death, immunocytochemistry experiments using selected monoclonal antibodies were performed. The histological sections of the cell types that were 
subjected to immunocytochemical analyzes are presented in Figure A1. Two epitopes (JIM8, JIM13) for AGP and three (LM1, LM11, JIM12) for extensins were used in this analysis. Because it is difficult to identify the separate fluorescence signals in the cell wall and plasma membrane using light microscopy, in the case of the AGP epitopes, these two compartments are described together. The signals inside the cells were localized in the intracellular compartments. The immunolocalisation of JIM8 showed almost a total absence of a fluorescence signal in any part of the control callus cells (Figure 5a-a"), which contrasted with a strong signal in the plasmalemma and intracellular compartment of cells from the material that had been treated with 5 and $50 \mu \mathrm{M}$ of 5 -azaC (Figure $5 \mathrm{~b}-\mathrm{b}^{\prime \prime}, \mathrm{c}-\mathrm{c}^{\prime \prime}, \mathrm{d}-\mathrm{d}^{\prime \prime}, \mathrm{e}-\mathrm{e}^{\prime \prime}$ ). The plasmolysis of some of the cells that had been treated with the higher concentration of the hypomethylating agent confirmed the fact that the localization of this epitope is in plasmalemma (Figure 5d", red arrows). In the control callus of Brachypodium, a patchy distribution of JIM13 in the cell wall and cytoplasmic compartments was observed (Figure 6a-a"). The callus that had been treated with $5 \mu \mathrm{M}$ of 5 -azaC was characterized by the presence of this epitope on the cell wall and intracellular compartments (Figure $6 \mathrm{~b}-\mathrm{b}^{\prime \prime}, \mathrm{c}-\mathrm{c}^{\prime \prime}$ ). In contrast, the callus that had been treated with $50 \mu \mathrm{M}$ of 5-azaC expressed the JIM13 signals in the cell wall and also had some weak signals in the intracellular compartments (Figure $\left.6 \mathrm{~d}-\mathrm{d}^{\prime \prime}, \mathrm{e}-\mathrm{e}^{\prime \prime}\right)$. Some of the cells were characterized by a total absence of signals (Figure 6d", $\mathrm{e}^{\prime \prime}$, red arrows).
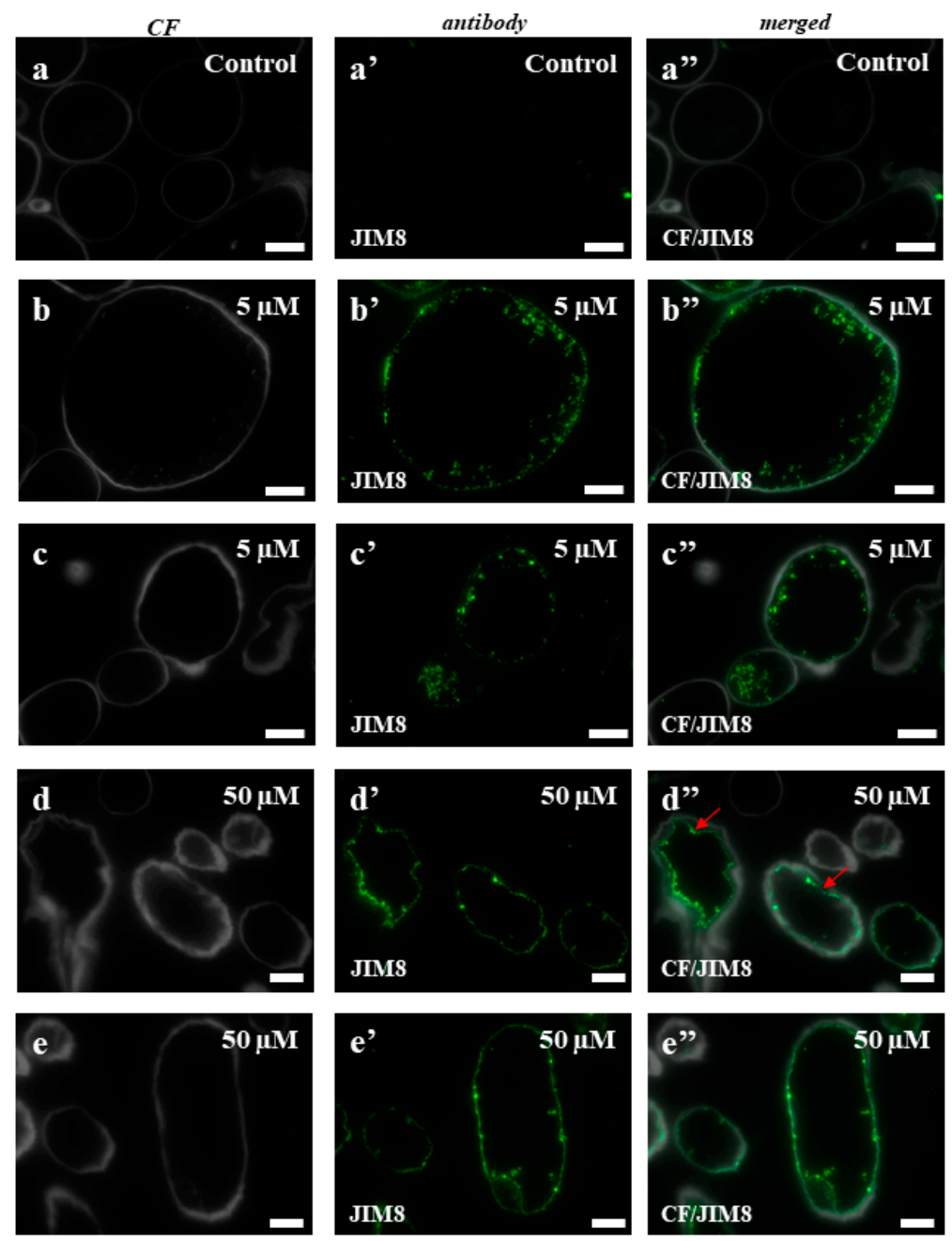

Figure 5. Immunolocalization of JIM8 in the Brachypodium callus. (a-a'): control callus; $\left(\mathbf{b}-\mathbf{b}^{\prime \prime}, \mathbf{c}-\mathbf{c}^{\prime \prime}\right)$ : callus that has been treated with $5 \mu \mathrm{M}$ of 5 -azaC. $\left(\mathbf{d}-\mathbf{d}^{\prime \prime}, \mathbf{e}-\mathbf{e}^{\prime \prime}\right)$ : callus that has been treated with $50 \mu \mathrm{M}$ of 5 -azaC. $\left(\mathbf{d}^{\prime \prime}\right)$ : red arrows demonstrate the detachment of the plasmalemma from the cell wall. Scale bars, $10 \mu \mathrm{m}$. 

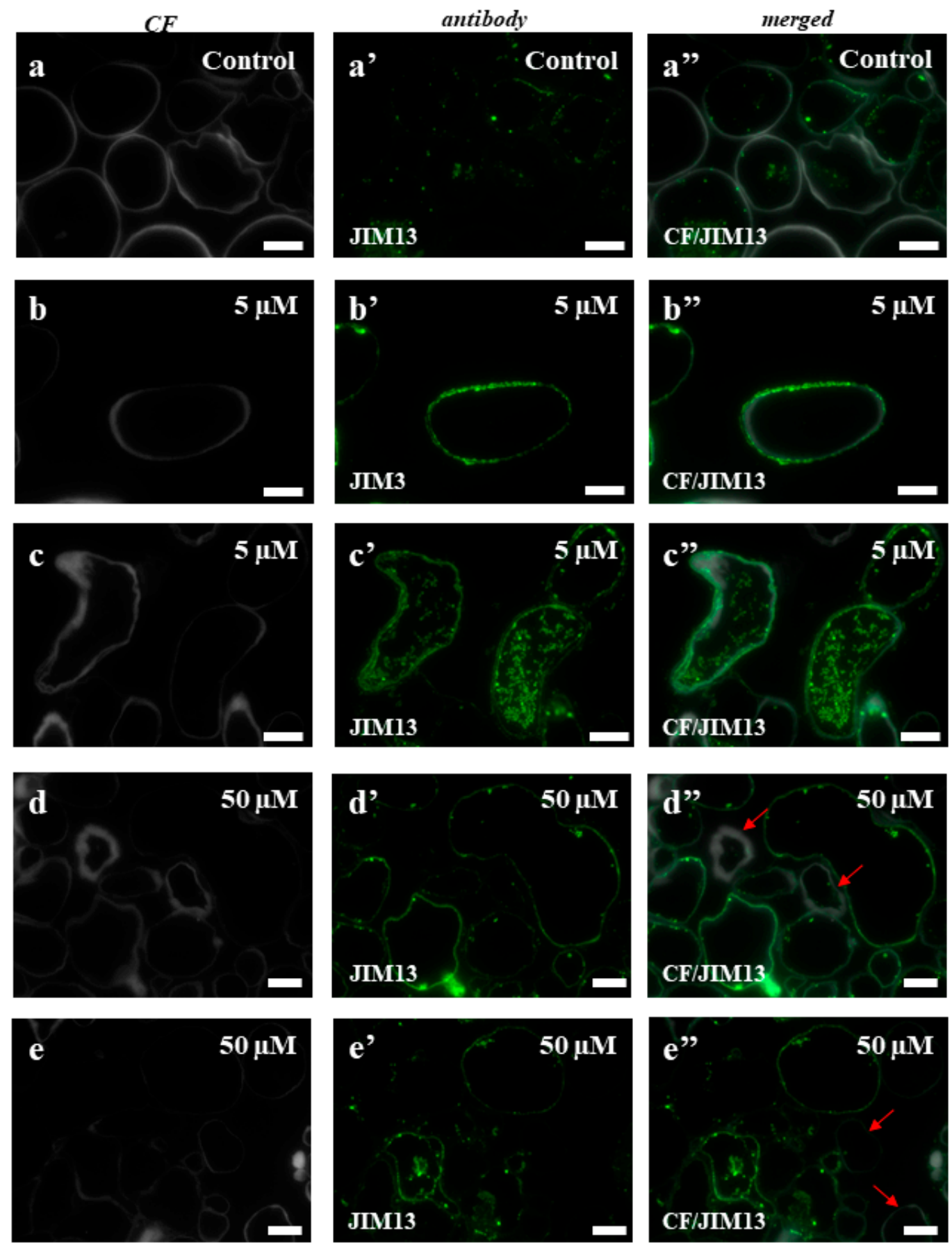

Figure 6. Immunolocalization of JIM13 in the Brachypodium callus. (a-a"): control callus. $\left(\mathbf{b}-\mathbf{b}^{\prime \prime}, \mathbf{c}-\mathbf{c}^{\prime \prime}\right)$ : callus that has been treated with $5 \mu \mathrm{M}$ of 5 -azaC. $\left(\mathbf{d}-\mathbf{d}^{\prime \prime}, \mathbf{e}-\mathbf{e}^{\prime \prime}\right)$ : callus that has been treated with $50 \mu \mathrm{M}$ of 5 -azaC. The cells with a total absence of the signals are indicated by red arrows. Scale bars, $10 \mu \mathrm{m}$.

In the case of the control callus, the experiments with the LM1 antibody showed the localization of this epitope in the intercellular spaces (Figure 7a-a"). The callus that had been treated with $5 \mu \mathrm{M}$ of 5-azaC displayed the presence of this epitope on the surface of some cells (Figure $7 \mathrm{~b}-\mathrm{b}^{\prime \prime}$ ), which contrasted with the intracellular localization of the signals from this antibody in the callus after the treatment with $50 \mu \mathrm{M}$ of 5 -azaC (Figure $7 \mathrm{c}-\mathrm{c}^{\prime \prime}, \mathrm{d}-\mathrm{d}^{\prime \prime}$ ). In the control, JIM11 only had signals in the intercellular spaces (Figure 8a-a"). The immunolocalization of JIM11 in the experimental material demonstrated the presence of weak signals in both the callus cells that had been treated with $5 \mu \mathrm{M}$ 
and $50 \mu \mathrm{M}$ of 5 -azaC (Figure $8 \mathrm{~b}-\mathrm{b}^{\prime \prime}, \mathrm{c}-\mathrm{c}^{\prime \prime}, \mathrm{d}-\mathrm{d}^{\prime \prime}, \mathrm{e}-\mathrm{e}^{\prime \prime}$ ). These signals, however, were found only outside the cell wall and in the cell wall of some callus cells. Interestingly, the JIM12 extensin epitope had an intercellular localization in both the treated and control calli (Figure 9). However, in the callus that had been treated with both concentrations of 5 -azaC, the signals of this antibody were almost absent (Figure 9b-b", $c-c^{\prime \prime}$ ).
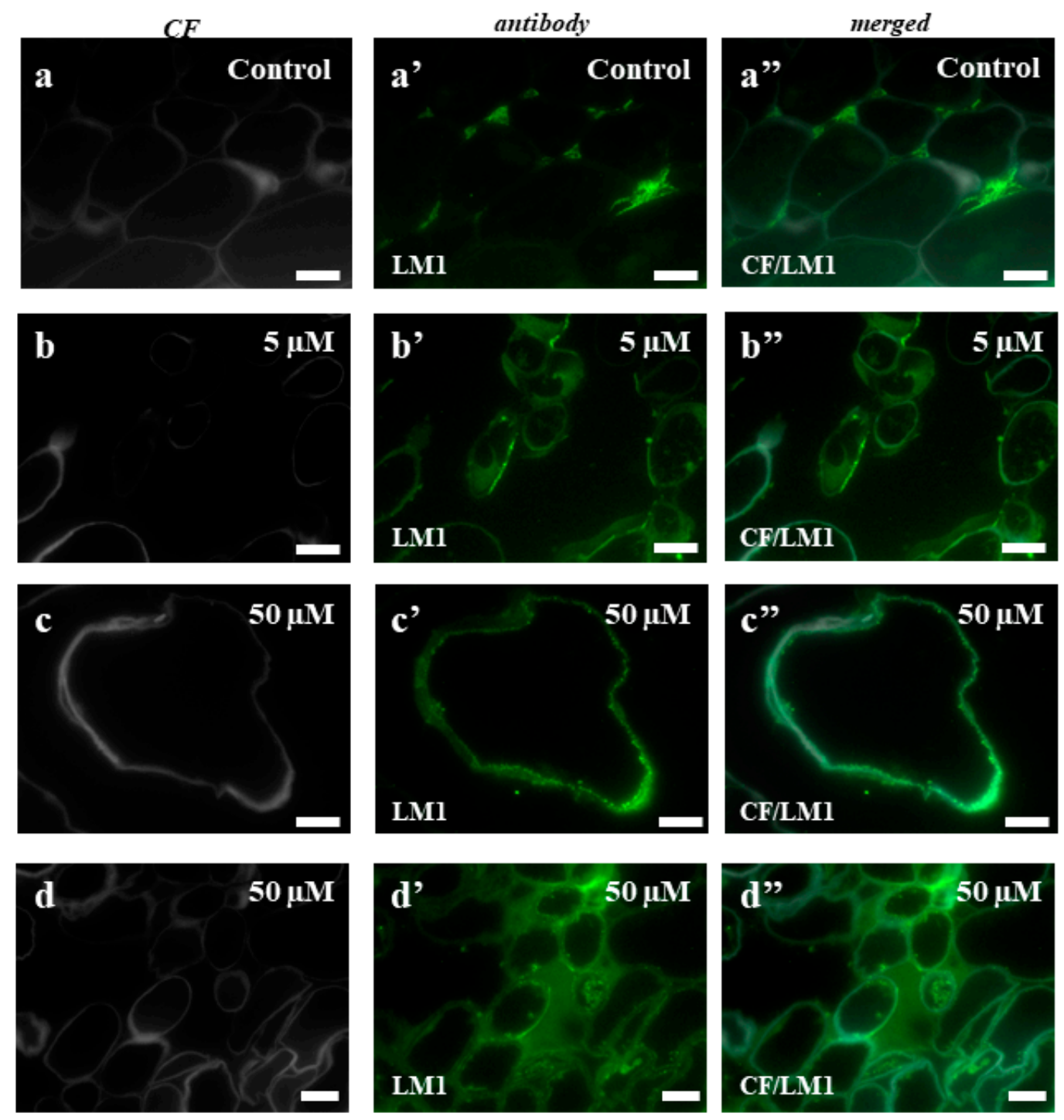

Figure 7. Immunolocalization of LM1 in the Brachypodium callus. (a-a"): control callus. (b-b"): callus that has been treated with $5 \mu \mathrm{M}$ of 5 -azaC. $\left(\mathbf{c}-\mathbf{c}^{\prime \prime}, \mathbf{d}-\mathbf{d}^{\prime \prime}\right)$ : callus that has been treated with $50 \mu \mathrm{M}$ of 5 -azaC. The greenish background on these photomicrographs is due to the autofluorescence. Scale bars, $10 \mu \mathrm{m}$. 

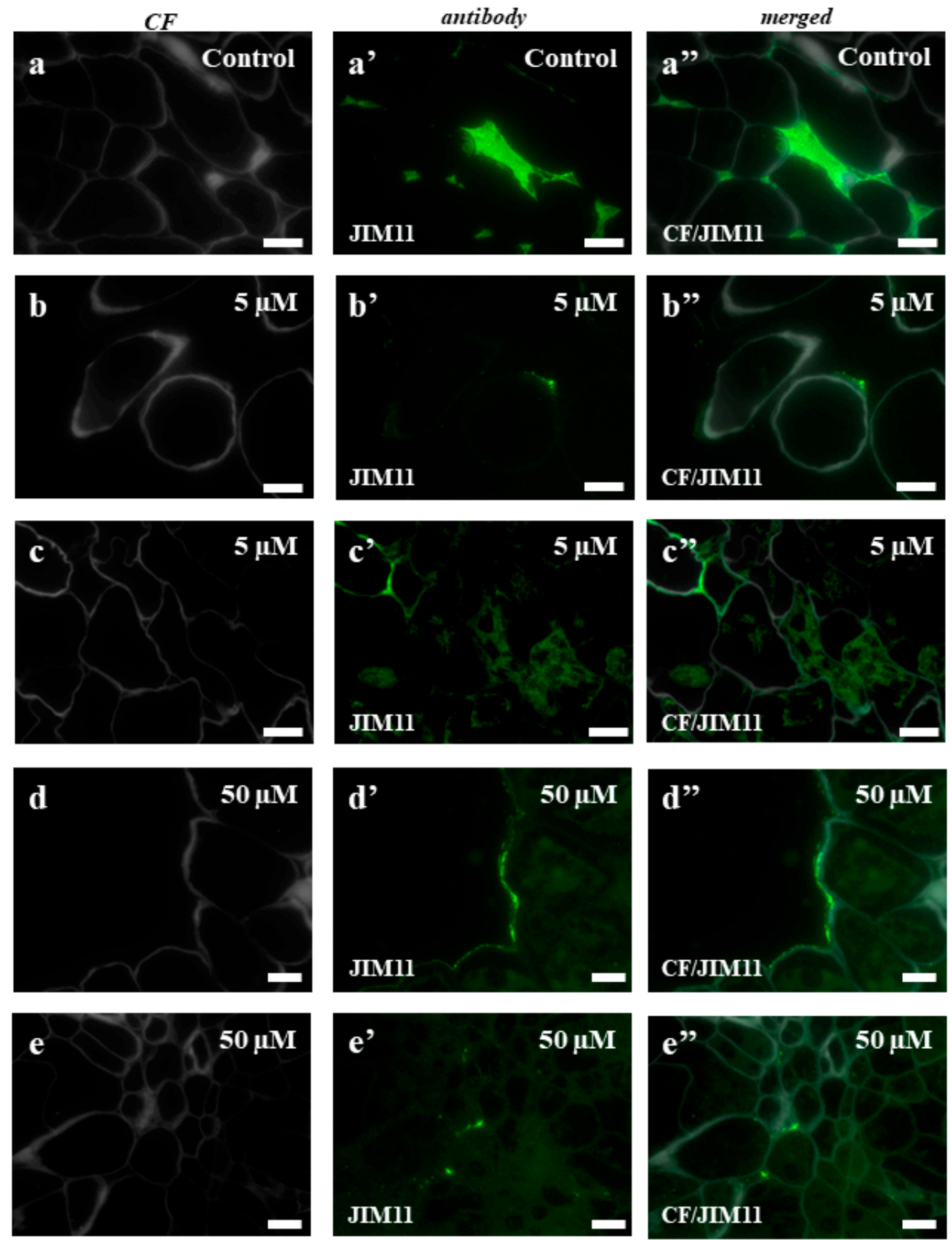

Figure 8. Immunolocalization of JIM11 in the Brachypodium callus. $\left(\mathbf{a}-\mathbf{a}^{\prime \prime}\right)$ : control callus. $\left(\mathbf{b}-\mathbf{b}^{\prime \prime}, \mathbf{c}-\mathbf{c}^{\prime \prime}\right)$ : callus that has been treated with $5 \mu \mathrm{M}$ of 5 -azaC. $\left(\mathbf{d}-\mathbf{d}^{\prime \prime}, \mathbf{e}-\mathbf{e}^{\prime \prime}\right)$ : callus that has been treated with $50 \mu \mathrm{M}$ of 5 -azaC. The greenish background on these photomicrographs is due to the autofluorescence. Scale bars, $10 \mu \mathrm{m}$. 

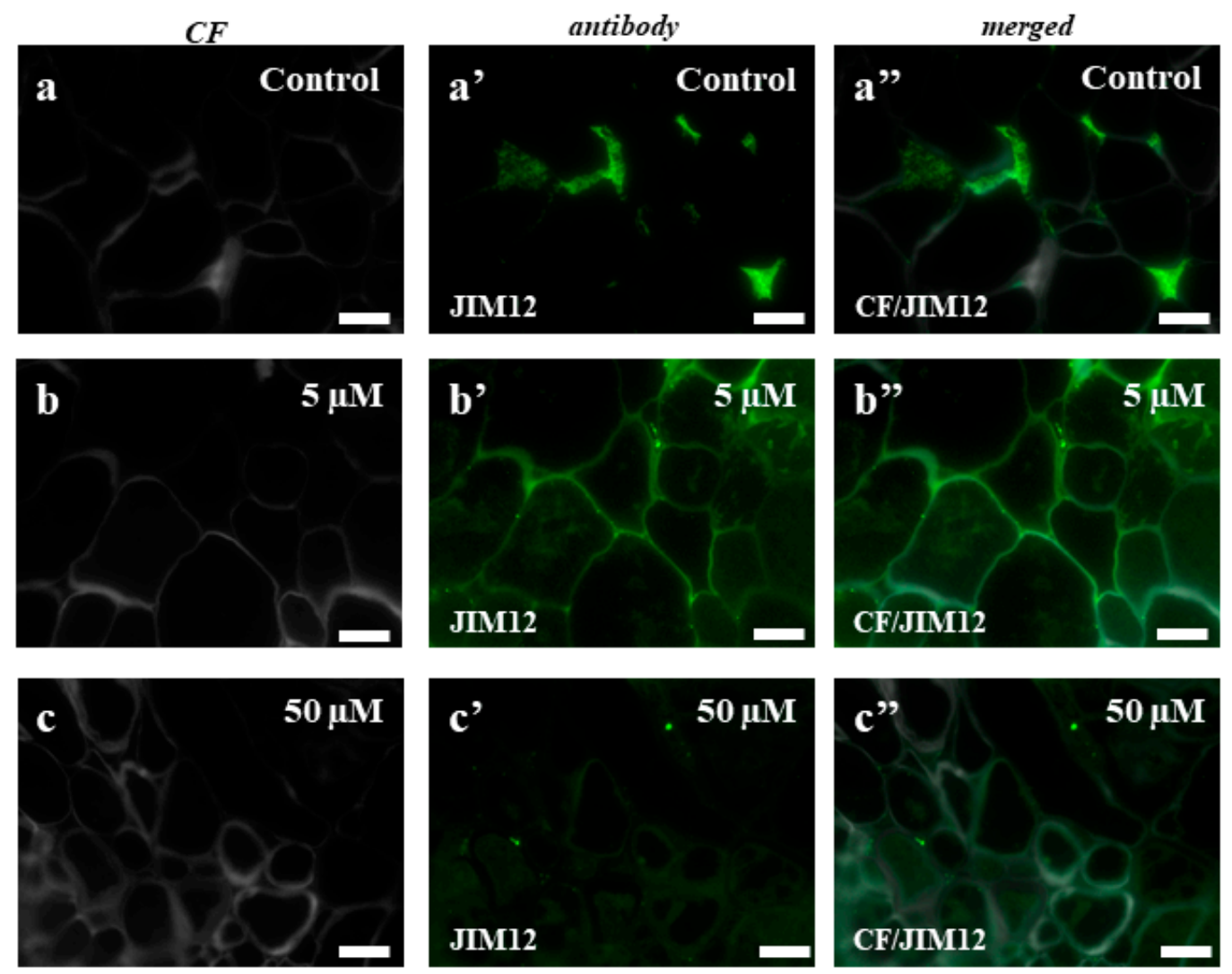

Figure 9. Immunolocalization of JIM12 in the Brachypodium callus. (a-a'): control callus. (b-b"): callus that has been treated with $5 \mu \mathrm{M}$ of 5 -azaC. $\left(\mathbf{c}-\mathbf{c}^{\prime \prime}\right)$ callus that has been treated with $50 \mu \mathrm{M}$ of 5 -azaC. The greenish background on these photomicrographs is due to the autofluorescence. Scale bars, $10 \mu \mathrm{m}$.

\section{Discussion}

In higher plants, DNA is strongly methylated on the cytosine residues. 5-azaC is a chemical analogue of cytosine that can be incorporated into the DNA structure during its replication, thereby replacing the cytosine residues therein. Such a substitution makes DNA methylation via the formation of 5-methylcytosines impossible. It has also been shown that the 5-azaC-induced DNA hypomethylation can restore transgene expression in long-term cultivated cell cultures of birch [25] and that changes in DNA-methylation can be induced under stress conditions [26-28]. In plants, the effect of the application 5-azaC appears to be species dependent. Solis et al. [29] demonstrated that it may promote the initiation of microspore embryogenesis by decreasing global DNA methylation, while a double treatment using 2,4-D and 5-azaC improved somatic embryo induction in a tissue culture of Acca sellowiana [30]. It was also revealed that treatment with 5-azaC caused both callus induction and somatic embryogenesis in Fraxinus mandshurica [31].

The results of our morphological and histological observations suggest that the fact that global DNA methylation was affected by 5-azaC does not play a pivotal role in the processes of callus formation. However, it does appear to be crucial for the formation of the EM. It is known that treatment with 5-azaC induces cell death in some cereals, for example in barley cells from the first leaf display an apoptotic pathway of cell death. The inhibition of nuclear DNA fragmentation during the development of the first leaf cells and an increase in the amount of DNA was also demonstrated in barley cells [32]. A similar way of cell death was demonstrated in the coleoptile and initial leaf seedlings during the early stages of wheat development $[6,33]$. 
It should be taken into account that 5 -azaC can have dose-dependent secondary effects and cell toxicity mediated by covalent trapping of DNA methyltransferase rather than by DNA demethylation itself [10,34-37]. In Arabidopsis and Thlaspi arvense, flowering time was advanced at $250 \mu \mathrm{M}$ of 5-azaC while higher concentrations were inhibitory to bolting and flower development [38]. It was demonstrated in Sorghum bicolor that 5-azaC concentration used for seedlings $(310 \mu \mathrm{M})$ proved to be toxic to calli [39]. In hybrid larch, treatment with $100 \mu \mathrm{M}$ of 5-azaC led to a dramatic decrease in the number of embryonal masses as well as embryogenic potential, which was attributed to 5-azaC toxicity [36]. To sum up, the decrease/absence of EMs on the surface of Brachypodium callus treated with 5-azaC may be due to the cytotoxic effect through the damage of DNA leading to cell death.

The ultrastructural changes within the cells that were observed during the culture with 5-azaC may indicate that the process of cell death is not necrosis. We propose that it may have the features of a programmed process. The traits described for cell death that were observed in this study indicate that it may be a vacuolar cell death, which is manifested by a gradual decrease in the volume of cytoplasm and a significant increase in the vacuole volume as well as volume presence of the cytoplasm content of the cells inside the vacuole compartment and the subsequent degradation of the cargo [40]. This type of cell death was also described during embryo development as well as during tissue and organ differentiation, which is either a normal part of the plant developmental program or a response to stressful conditions [41-45]. Interestingly, in our research, we observed the increasing number of plastoglobuli, which may be linked with the upregulation of plastid lipid metabolism in response to oxidative stress provoked by 5 -azaC. It was demonstrated that the number of plastoglobules increases in plants subjected to environmental conditions-such as drought, high saline concentrations, viral infections, and increased ozone concentration-which increases the oxidative stress on the photosynthetic apparatus [46-49].

The TUNEL assay is widely used to confirm the presence of double-strand breaks (DSBs) $[19,50,51]$. Using this approach, it was demonstrated that the surface cells covering the somatic embryos of Daucus carota underwent cell death before peeling off [52]. It was also successfully applied to demonstrate cell death after the addition of the Yariv reagent to Arabidopsis cell cultures [24]. In our research, use of the TUNEL assay demonstrated the presence of TUNEL-positive cells on the seventh day of cultivation and they were represented by almost $100 \%$ of the cells, which could indicate the presence of cell death. It should be noted that TUNEL-positive control nuclei were observed at a frequency of $8.7 \%$, thus confirming the well-known fact that DSBs can be generated spontaneously [6].

As we found almost all of the TUNEL-positive cells on the seventh day of cultivation, we chose this day to analyze the particular expression of the genes that participate in cell death in Brachypodium callus using RT-PCR. As was mentioned earlier, the strongest expression was characteristic for GSTs, which are ubiquitous enzymes that catalyze the conjugation of toxic xenobiotics and oxidatively produced compounds to reduced glutathione, which facilitates the metabolism of toxic substances, sequestration, or removal [53]. The importance of this family of enzymes is confirmed by their abundance in a cell, since they contribute to at least $1 \%$ of the total amount of cell proteins [17]. The genome of Arabidopsis contains 48 GST-like genes [54]. The influence of adverse biotic and abiotic factors on the cells induce the expression of GST genes [18,55]. Such factors may include dehydration, herbicides, damage, cold, hypoxia, $\mathrm{H}_{2} \mathrm{O}_{2}$, UV, phosphate starvation, metal ions, high salt concentrations, and pathogens. It should be noted that the activity of GST may be also connected with TRX and that particular TRXs may also be reduced via the glutathione/glutaredoxin system [56]. In our experiments on the Brachypodium callus, we observed a decrease in the TRX expression. Cultivation of the callus in the dark together with the 5-azaC treatment could lead to the inactivation of TRXs. The importance of light for TRX activation was demonstrated for the potato plastidic enzymes, which are inactive due to the oxidized state of their critical cysteinyl residues in the dark [57].

Metacaspase seems to be very important in determining the mode of cell death as was demonstrated for vacuolar death in the embryo suspensor of Norway spruce, which required autophagy [58]. The activation of autophagy was connected with the downstream signaling 
of metacaspase mcII-Pa. These authors highlighted that the genetic suppression of the metacaspase-autophagy pathway induced a switch from a vacuolar to a necrotic cell death. In the present work, we show a decrease in the expression on the metacaspase, which corroborates the results of TEM analyzes, where we observed the typical features of the vacuolar cell death. A decrease in the expression of EX1 was also observed in this work. EX1 and EX2 are plastid proteins and their inactivation in the $f l u$ mutant of Arabidopsis led to the loss of chloroplast integrity that precedes the rupture of the central vacuole and the final collapse of a cell [59]. The expression levels of both EX1 and EX2 increase during biotic and abiotic stress in wild type plants. Thus, the chloroplasts may serve as sensors of the environmental changes that activate a broad range of stress responses [16]. A decrease of the expression level of EX1 in the Brachypodium callus appears to be connected with the absence of a developed chloroplast system. Since the Brachypodium callus was cultivated in the dark, its cells only contained proplastids that were deprived of a prolamellar body along with some loosely associated membranes (Figure 2h,i), which may be one of the reasons for the EX1 inactivation. Another rationale might be the accumulation of reactive oxygen species after cultivation with 5 -azaC, which leads to a decrease in the EX1 expression.

The epitopes of AGPs and extensins were selected for the studies presented here because of their known role in different developmental processes [20,21,60,61], including somatic embryogenesis [61-63] and cell death [24,64]. Our results showed that the distribution of these AGP and extensin epitopes differed in the treated callus compared to the control explants and that the reaction to 5-azaC was dose dependent. Moreover, all of the detected changes in the presence of the tested epitopes were typical for the cells, which exhibited features on the cellular and ultrastructural level indicate that they undergo death other than necrosis, and as we postulate, it is a vacuolar cell death. AGPs can be considered to be molecular markers of cell death during microsporogenesis in Arabidopsis, where it was revealed that the tapetum cells show the morphological features that are typical for programmed cell death and have the high presence of AGPs recognized by JIM8 and JIM13 during their degeneration [65]. It has also been documented that the epitopes of AGPs are recognized by the JIM13 and JIM14 antibodies, which are associated with cells that are committed to programmed cell death [66]. In our work, we used two monoclonal antibodies, JIM8 and JIM13, that recognize the AGP epitopes and both of these showed the strongest signals in the callus that had been treated with 5 -azaC and were almost absent in the control callus. These results may suggest that in the Brachypodium callus that had been treated with 5-azaC, the cells that are "decorated" by these signals undergo cell death, and if so, these epitopes may serve as the molecular markers of cell death.

Unlike AGPs, the immunodetection of extensins in the Brachypodium explants demonstrated a decrease in the fluorescence signals of each epitope in the callus that had been treated with 5-azaC that was analyzed. In the cell walls of bean cell suspensions during habituation and dehabituation to dichlobenil, the HPRG epitope that is recognized by LM1 was detected throughout the cell walls of the non-habituated cell clusters and the epitope appeared mainly in the cell wall corners and on the outer surfaces of the walls in the habituated cells [67]. A similar distribution of this epitope was detected in the Brachypodium callus that had been treated with 5-azaC. During the somatic embryogenesis of banana, it was shown that the HRGP that is recognized by JIM11 was present in a very small amount in the nonembryogenic part of explant, but that a moderate fluorescence signal was found only at the surface of the cell aggregates [61]. The same studies showed that the JIM11 epitope was abundant in the cell walls and especially in the tricellular junctions of the inner cortical cells. A similar distribution was found in our study on Brachypodium.

Based on these results, the main function of extensins in the Brachypodium callus is postulated to be 'fixing' the cells among each other as we found strong fluorescence signals in the intracellular spaces and their almost total absence in the callus that had been treated with 5-azaC. As was demonstrated earlier, during the final stages of cell death, the collapse of the cell walls into crushed layers requires their structural reorganization [65]. An extensin scaffold appears to be one of the most important components that is required for the self-assembly of the plant cell wall [68]. Research on an Arabidopsis 
mutant with a lethal knockout of a single extensin gene (AtEXT3) designated root-, shoot-, and hypocotyl-defective during embryogenesis was typified by an incomplete cross wall assembly [69]. These authors found that a defective wall assembly is a direct consequence of the absence of AtEXT3 and concluded that a protein containing hydroxyproline is an integral part of the cell wall of actively growing cells. The entrance of cells into the pathway that leads to death is accompanied by changes in the epitopes of AGPs and extensins that were analyzed.

\section{Materials and Methods}

\subsection{Plant Material Growth, In Vitro Culture Conditions, and 5-azaC Treatment}

The embryogenic callus was obtained according to Betekhtin et al. [2]. Zygotic embryos (ZEs) were cultivated on a callus induction medium (CIM) that had been supplemented with 5 and $50 \mu \mathrm{M}$ of 5-azaC as well as on a CIM medium with no 5-azaC (control). For each experiment, 100 ZEs were used. One passage of cultivation took 21 days and the material was collected and analyzed on the 7th, 14th, and 21st days of cultivation.

\subsection{Histological Procedures}

The procedures for embedding tissues in Steedman's wax [70] and preparing the slides were done according to Wolny et al. [71]. For the toluidine blue staining, slides with tissue sections were de-embedded three times for $10 \mathrm{~min}$ in $99.8 \%$ ethanol and rehydrated in ethanol/distilled water for $10 \mathrm{~min}$ at each step $(90 \%, 70 \%, 50 \%, 30 \% v / v$, distilled water). The slides were then placed in an aqueous $0.01 \%$ toluidine blue solution for $10 \mathrm{~min}$ and rinsed three times in distilled water for 5 min each. The stained slides were then air dried and embedded in a mounting medium (DPX, Sigma-Aldrich, St. Louis, MO, USA). Images of the stained tissue sections were obtained using an Axio Imager Z2 microscope equipped with an AxioCam camera (Zeiss, Oberkochen, Germany).

\subsection{TEM}

For the TEM studies, a morphogenic callus of Brachypodium was fixed in $2.5 \%$ glutaraldehyde in a $0.1 \mathrm{M}$ sodium phosphate buffer (PB; $\mathrm{pH} 7.4$ ) at $4{ }^{\circ} \mathrm{C}$ for $24 \mathrm{~h}$. After washing in phosphate buffered saline (PBS, 5 times, 30 min each), the material was postfixed in $1 \%$ osmium tetroxide in a $0.1 \mathrm{M} \mathrm{PB}$ $\left(4{ }^{\circ} \mathrm{C}, 24 \mathrm{~h}\right)$, rinsed with the same buffer and dehydrated in a graded concentration series of ethanol (30\%, 50\%, 70\%, 90\%, 96\%, and 100\%, each for $15 \mathrm{~min}$ ) and acetone (two times, $15 \mathrm{~min}$ each) followed by infiltration in mixtures of acetone and Epon 812 resin (3:1, 1:1, and 1:3) (Polysciences, Eppelheim, Germany). Then, the material was embedded in Epon 812 resin and polymerized into resin blocks at $60^{\circ} \mathrm{C}$ for $48 \mathrm{~h}$. Ultra-thin $(70 \mathrm{~nm})$ sections were cut with a diamond knife on an Ultracut UCT25 (Leica, Wetzlar, Germany) ultramicrotome. After contrast staining with uranyl acetate and lead citrate, the sections were examined using a H500 transmission electron microscope (Hitachi, Tokyo, Japan).

\subsection{TUNEL Assay}

The TUNEL methodology was according to Kwasniewska et al. [72]. The callus tissue was fixed with $4 \%$ paraformaldehyde for $1 \mathrm{~h}$ at room temperature on the seventh day of cultivation and then washed $3 \times$ for $5 \mathrm{~min}$ in PBS. The squashed slides with nuclei were prepared in PBS and were frozen at $-70{ }^{\circ} \mathrm{C}$ and air dried at room temperature. Next, the slides were incubated in a permeabilization solution $\left(0.1 \%\right.$ Triton X-100 in $0.1 \%$ sodium citrate) for 2 min at $4{ }^{\circ} \mathrm{C}$, and then rinsed with PBS. The positive control was prepared by adding $50 \mu \mathrm{L}$ of a DNase solution $(250 \mu \mathrm{g} / \mathrm{mL})$ to a slide that had been prepared from the control material for $30 \mathrm{~min}$ at $37^{\circ} \mathrm{C}$ in a humid chamber. After DNase treatment, the slides were rinsed twice with PBS. DNA fragment labelling was carried out using the TUNEL reaction mixture (In Situ Cell Death Detection Kit, Fluorescein, Sigma-Aldrich, St. Louis, MO, USA). A $50 \mu \mathrm{L}$ measure of the TUNEL reaction mixture (enzyme: fluorescein-labelled nucleotides, $1: 9$ ratio, $v / v$ ) was added to the preparation and incubated in a humid chamber in the dark for $1 \mathrm{~h}$ at 
$37^{\circ} \mathrm{C}$. For the negative control, only $50 \mu \mathrm{L}$ of the reaction mixture without terminal transferase was used. The slides were rinsed $3 \times$ with PBS.

The slides were stained with DAPI $(2 \mu \mathrm{g} / \mathrm{mL})$ and mounted in Vectashield (Vector Laboratories, Peterborough, United Kingdom). Preparations were examined with an Axio Imager Z2 wide-field fluorescence microscope equipped with an AxioCam Mrm monochromatic camera and the appropriate sets of filters (Zeiss). The frequency estimation of the labelled nuclei was based on an analysis of at least 500 cells from two slides for each treatment and period/duration of culturing.

\subsection{Gene Expression Analysis}

Trizol (Invitrogen, Carlsbad, CA, USA) plus RNeasy Mini Kit (Qiagen, Hilden, Germany) was used to isolate total RNA from the ZEs [73] and 200 explants were used for each biological replicate. The concentration and quality of the isolated RNA was evaluated using an ND-1000 NanoDrop spectrophotometer (Waltham, MA, USA). First-strand cDNA was produced using a Maxima H Minus First Strand cDNA Synthesis Kit with dsDNase (Thermo Scientific, Waltham, MA, USA). The product of the reverse transcription was diluted with water at a 4:1 ratio and $2 \mu \mathrm{L}$ of this solution was used for the Real Time RT-qPCR reactions using a LightCycler ${ }^{\circledR} 480$ SYBR Green I Master in a LightCycler ${ }^{\circledR}$ 480 Real-Time PCR System (Roche, Basel, Switzerland). The primers that were relevant to the genes that were studied are listed in Table 1 . The relative RNA levels were calculated and normalized to an internal control, the AK437296 gene encoding ubiquitin. This control gene exhibited a constant expression pattern $\left(C_{t}=17 \pm 1\right)$ in all of the tissue samples that were analyzed. The plant tissues for the real-time RT-qPCR analysis were produced in three biological repetitions and two technical replicates of each repetition were carried out. The relative expression level was calculated using $2^{-\mathrm{ddCt}}$, where $\mathrm{dd} C_{\mathrm{t}}$ represents $\mathrm{d} C_{\mathrm{t}}$ reference condition $-\mathrm{d} C_{\mathrm{t}}$ compared condition.

\subsection{Immunocytochemistry}

The fixation and embedding procedure was prepared according to Betekhtin et al. [2]. Sections were incubated in a blocking buffer containing $2 \%(v / v)$ foetal calf serum (FCS) and $2 \%(w / v)$ bovine serum albumin (BSA) in PBS (pH 7.2) for $30 \mathrm{~min}$ at room temperature. Next, they were incubated with specific primary monoclonal antibodies (Table 2), diluted at a ratio of 1:20 in a blocking buffer (room temperature, minimum $1.5 \mathrm{~h}$ ), rinsed with the blocking buffer $3 \times 10 \mathrm{~min}$ and then incubated at room temperature for at least $1.5 \mathrm{~h}$ with the secondary antibody (Alexa Fluor 488 goat anti-rat IgG, Jackson Immuno-Research Laboratories, West Grove, PA, USA), which was diluted at a ratio of 1:100 in the blocking buffer as above. After washing with the blocking buffer and PBS $(3 \times 10 \mathrm{~min}$ each), the sections were stained with $0.01 \%(w / v)$ calcofluor (Sigma-Aldrich, St. Louis, MO, USA) in PBS for $5 \mathrm{~min}$, then the slides were thoroughly rinsed with PBS and sterile distilled water $(3 \times 10 \mathrm{~min}$ each). Drained slides were mounted in a Fluoromount (Sigma-Aldrich) antifade medium. Negative controls were performed for each antibody that was used by omitting the primary antibodies. The greenish background on the figures is presence as the results of autofluorescence because the stronger exposure time was applied. This procedure because of the weaker fluorescence signals from antibodies in experiments with 5-azaC compare to control cells was done. All images were taken using an Axio Imager Z2 epifluorescence microscope equipped with an AxioCam Mrm monochromatic camera (Zeiss) with the narrow-band filters for AlexaFluor 488 and DAPI. For general histology, the sections were stained with a $0.05 \%(w / v)$ toluidine blue $\mathrm{O}$ for $5 \mathrm{~min}$. 
Table 2. Antibodies used for immunocytochemistry, the epitopes they recognize, and relevant references.

\begin{tabular}{ccc}
\hline Antibody & Epitope & References \\
\hline & Arabinogalactan proteins (AGPs) & \\
\hline JIM8 & Arabinogalactan & {$[74]$} \\
JIM13 & (beta)GlcA1 $\rightarrow$ 3(alpha)GalA1 $\rightarrow$ 2Rha & {$[75]$} \\
\hline LM1 & Extensins & {$[76]$} \\
JIM11 & Extensin & {$[77]$} \\
JIM12 & Extensin & {$[77]$} \\
\hline
\end{tabular}

\section{Conclusions}

We have demonstrated that Brachypodium tissue culture can be a useful model system to reveal the influence of 5-azaC during the formation of EM in grasses as well as for studying cell death in monocotyledonous plants. Future work including analyzes of SE induction in Brachypodium of the genes encoding for DNA methylases/demethylases should be considered.

Author Contributions: Conceptualization, A.B.; Data curation, A.B.; Formal analysis, A.B., A.M.-H., L.C., K.N., and J.K.; Funding acquisition, E.K. and R.H.; Investigation, A.B., A.M.-H., L.C., M.R., K.N., J.K., and E.W.; Methodology, A.B., A.M.-H., L.C., M.R., K.N., J.K., and E.W.; Project administration, A.B., E.K., and R.H.; Resources, E.K. and R.H.; Supervision, A.B., E.K., and R.H.; Visualization, A.B., A.M.-H., M.R., J.K., and E.W.; Writing-original draft, A.B., A.M.-H., M.R., K.N., J.K., E.K., and R.H.

Funding: This work was supported by the National Science Centre Poland (grant DEC-2014/14/M/NZ2/00519)

Conflicts of Interest: The authors declare no conflict of interest.

\section{Appendix A}
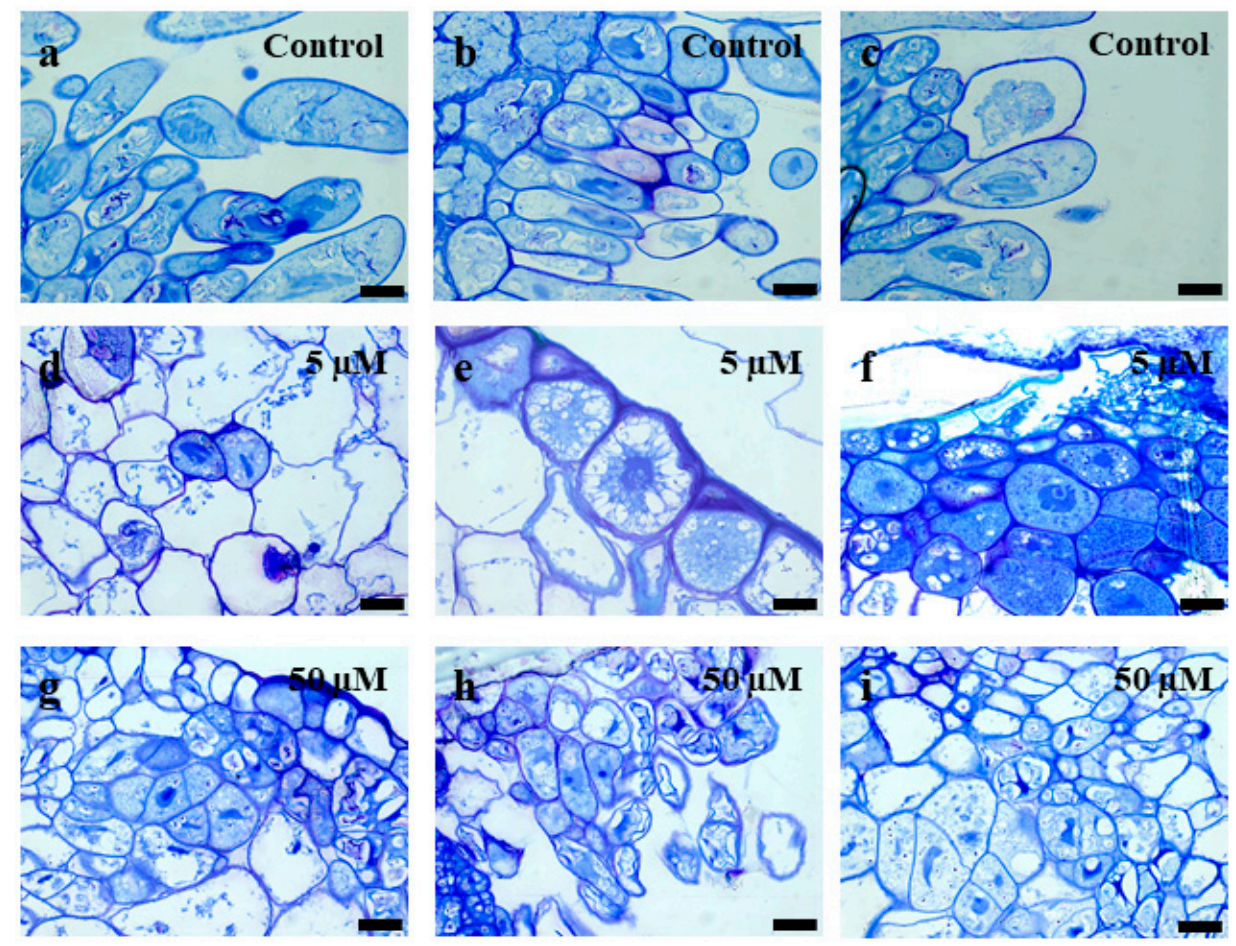

Figure A1. Histological sections of the Brachypodium callus stained with a $0.05 \%(w / v)$ toluidine blue O. $(\mathbf{a}-\mathbf{c})$ : control callus; $(\mathbf{d}-\mathbf{f})$ : callus that has been treated with $5 \mu \mathrm{M}$ of 5 -azaC. (g-i): callus that has been treated with $50 \mu \mathrm{M}$ of 5-azaC. Scale bars, $10 \mu \mathrm{m}$. 


\section{References}

1. Rancour, D.M.; Marita, J.M.; Hatfield, R.D. Cell wall composition throughout development for the model grass Brachypodium distachyon. Front. Plant Sci. 2012, 3, 266. [CrossRef] [PubMed]

2. Betekhtin, A.; Rojek, M.; Milewska-Hendel, A.; Gawecki, R.; Karcz, J.; Kurczynska, E.; Hasterok, R. Spatial distribution of selected chemical cell wall components in the embryogenic callus of Brachypodium distachyon. PLoS ONE 2016, 11, e0167426. [CrossRef] [PubMed]

3. Jung, H.I.; Gayomba, S.R.; Yan, J.; Vatamaniuk, O.K. Brachypodium distachyon as a model system for studies of copper transport in cereal crops. Front. Plant Sci. 2014, 5, 236. [CrossRef] [PubMed]

4. Oliveira, E.J.; Koehler, A.D.; Rocha, D.I.; Vieira, L.M.; Pinheiro, M.V.; de Matos, E.M.; da Cruz, A.C.; da Silva, T.C.; Tanaka, F.A.; Nogueira, F.T.; et al. Morpho-histological, histochemical, and molecular evidences related to cellular reprogramming during somatic embryogenesis of the model grass Brachypodium distachyon. Protoplasma 2017, 254, 2017-2034. [CrossRef] [PubMed]

5. Kurczynska, E.U.; Potocka, I.; Dobrowolska, I.; Kulinska-Lukaszek, K.; Sala, K.; Wrobel, J. Cellular markers for somatic embryogenesis. In Embryogenesis; Sato, K.-I., Ed.; InTech: Rijeka, Croatia, 2012; Chapter 14; pp. 307-332. Available online: https:/ /www.intechopen.com/download/pdf/35572 (accessed on 13 June 2018).

6. Vanyushin, B.F.; Ashapkin, V.V. DNA methylation in higher plants: Past, present and future. Biochim. Biophys. Acta 2011, 1809, 360-368. [CrossRef] [PubMed]

7. Matzke, M.A.; Primig, M.; Trnovsky, J.; Matzke, A.J. Reversible methylation and inactivation of marker genes in sequentially transformed tobacco plants. EMBO J. 1989, 8, 643-649. [PubMed]

8. Saze, H.; Tsugane, K.; Kanno, T.; Nishimura, T. DNA methylation in plants: Relationship to small RNAs and histone modifications, and functions in transposon inactivation. Plant Cell Physiol. 2012, 53, 766-784. [CrossRef] [PubMed]

9. Shibuya, K.; Fukushima, S.; Takatsuji, H. RNA-directed DNA methylation induces transcriptional activation in plants. Proc. Natl. Acad. Sci. USA 2009, 106, 1660-1665. [CrossRef] [PubMed]

10. Yamamoto, N.; Kobayashi, H.; Togashi, T.; Mori, Y.; Kikuchi, K.; Kuriyama, K.; Tokuji, Y. Formation of embryogenic cell clumps from carrot epidermal cells is suppressed by 5-azacytidine, a DNA methylation inhibitor. Plant Phys. J. 2005, 162, 47-54. [CrossRef] [PubMed]

11. Quinga, L.A.; Fraga, H.; Nascimento Vieira, L.; Guerra, M.P. Epigenetics of long-term somatic embryogenesis in Theobroma cacao L.: DNA methylation and recovery of embryogenic potential. PCTOC 2017, 131, $295-305$. [CrossRef]

12. Finnegan, E.J.; Genger, R.K.; Kovac, K.; Peacock, W.J.; Dennis, E.S. DNA methylation and the promotion of flowering by vernalization. Proc. Natl. Acad. Sci. USA 1998, 95, 5824-5829. [CrossRef] [PubMed]

13. Vanyushin, B.F.; Shorning, B.Y.; Seredina, A.V.; Aleksandrushkina, N.I. The effects of phytohormones and 5-azacytidine on apoptosis in etiolated wheat seedlings. Russ. J. Plant Physiol. 2002, 49, 501-506. [CrossRef]

14. Griffin, P.T.; Niederhuth, C.E.; Schmitz, R.J. A Comparative analysis of 5-azacytidine- and zebularine-induced DNA demethylation. G3 (Bethesda) 2016, 6, 2773-2780. [CrossRef] [PubMed]

15. Ning, S.B.; Wang, L.; Song, Y.C. Identification of programmed cell death in situ in individual plant cells in vivo using a chromosome preparation technique. J. Exp. Bot. 2002, 53, 651-658. [CrossRef] [PubMed]

16. Lee, K.P.; Kim, C.; Landgraf, F.; Apel, K. EXECUTER1- and EXECUTER2-dependent transfer of stress-related signals from the plastid to the nucleus of Arabidopsis thaliana. Proc. Natl. Acad. Sci. USA 2007, 104, 10270-10275. [CrossRef] [PubMed]

17. Salinas, A.E.; Wong, M.G. Glutathione S-transferases a review. Curr. Med. Chem. 1999, 6, 279-309. [PubMed]

18. Sharma, R.; Sahoo, A.; Devendran, R.; Jain, M. Over-expression of a rice tau class glutathione s-transferase gene improves tolerance to salinity and oxidative stresses in Arabidopsis. PLoS ONE 2014, 9, e92900. [CrossRef] [PubMed]

19. Gavrieli, Y.; Sherman, Y.; Ben-Sasson, S.A. Identification of programmed cell death in situ via specific labeling of nuclear DNA fragmentation. J. Cell Biol. 1992, 119, 493-501. [CrossRef] [PubMed]

20. Larkins, B.A.; Vasil, I.K. Cellular and Molecular Biology of Plant Seed Development; Kluwer Academic Publishers: Dordrecht, The Netherlands; Boston, MA, USA, 1997; 648p.

21. Nothnagel, E.A.; Bacic, A.; Clarke, A.E. Cell and Developmental Biology of Arabinogalactan-Proteins; Kluwer Academic: New York, NY, USA; London, UK, 2000; 301p. 
22. Nothnagel, E.A. Proteoglycans and related components in plant cells. Int. Rev. Cytol. 1997, 174, $195-291$. [PubMed]

23. Showalter, A.M. Arabinogalactan-proteins: Structure, expression and function. Cell. Mol. Life Sci. 2001, 58, 1399-1417. [CrossRef] [PubMed]

24. Gao, M.; Showalter, A.M. Yariv reagent treatment induces programmed cell death in Arabidopsis cell cultures and implicates arabinogalactan protein involvement. Plant J. 1999, 19, 321-331. [CrossRef] [PubMed]

25. Zeng, F.; Qian, J.; Luo, W.; Zhan, Y.; Xin, Y.; Yang, C. Stability of transgenes in long-term micropropagation of plants of transgenic birch (Betula platyphylla). Biotechnol. Lett. 2010, 32, 151-156. [CrossRef] [PubMed]

26. Zhong, L.; Yan-hao, X.; Wang, J. DNA-methylation changes induced by salt stress in wheat Triticum aestivum. Afr. J. Biotechnol. 2009, 8, 6201-6207.

27. Chwialkowska, K.; Nowakowska, U.; Mroziewicz, A.; Szarejko, I.; Kwasniewski, M. Water-deficiency conditions differently modulate the methylome of roots and leaves in barley (Hordeum vulgare L.). J. Exp. Bot. 2016, 67, 1109-1121. [CrossRef] [PubMed]

28. Seymour, D.K.; Becker, C. The causes and consequences of DNA methylome variation in plants. Curr. Opin. Plant Biol. 2017, 36, 56-63. [CrossRef] [PubMed]

29. Solis, M.T.; El-Tantawy, A.A.; Cano, V.; Risueno, M.C.; Testillano, P.S. 5-azacytidine promotes microspore embryogenesis initiation by decreasing global DNA methylation, but prevents subsequent embryo development in rapeseed and barley. Front. Plant Sci. 2015, 6, 472. [CrossRef] [PubMed]

30. Fraga, H.P.; Vieira, L.N.; Caprestano, C.A.; Steinmacher, D.A.; Micke, G.A.; Spudeit, D.A.; Pescador, R.; Guerra, M.P. 5-Azacytidine combined with 2,4-D improves somatic embryogenesis of Acca sellowiana (O. Berg) Burret by means of changes in global DNA methylation levels. Plant Cell Rep. 2012, 31, 2165-2176. [CrossRef] [PubMed]

31. Yan, L.; Hailong, S.; Jianmin, C. Effect of 5-azacytidine on zygotic cotyledon explants and somatic embryogenesis of Fraxinus mandshurica. Northeast For. Univ. J. 2011, 8, $25-27$.

32. Shkute, N.; Stivrina, N. 5-Azacytidine decreases fragmentation of nuclear DNA and pigment formation in first leaf cells of barley seedlings. Cell Biol. Int. 2005, 29, 1025-1031. [CrossRef] [PubMed]

33. Vanyushin, B.F.; Bakeeva, L.E.; Zamyatnina, V.A.; Aleksandrushkina, N.I. Apoptosis in plants: Specific features of plant apoptotic cells and effect of various factors and agents. Int. Rev. Cytol. 2004, 233, 135-179. [PubMed]

34. Kiziltepe, T.; Hideshima, T.; Catley, L.; Raje, N.; Yasui, H.; Shiraishi, N.; Okawa, Y.; Ikeda, H.; Vallet, S.; Pozzi, S.; et al. 5-Azacytidine, a DNA methyltransferase inhibitor, induces ATR-mediated DNA double-strand break responses, apoptosis, and synergistic cytotoxicity with doxorubicin and bortezomib against multiple myeloma cells. Mol. Cancer Ther. 2007, 6, 1718-1727. [CrossRef] [PubMed]

35. Fuller, J. The Effects of 5-Azacytidine on Transformed Hairy Root Cultures of Artemisia Annua. Ph.D. Thesis, Worcester Polytechnic Institute, Worcester, MA, USA, 2006.

36. Teyssier, C.; Maury, S.; Beaufour, M.; Grondin, C.; Delaunay, A.; Le Mette, C.; Ader, K.; Cadene, M.; Label, P.; Lelu-Walter, M.A. In search of markers for somatic embryo maturation in hybrid larch (Larix $\times$ eurolepis): Global DNA methylation and proteomic analyzes. Physiol. Plant. 2014, 150, 271-291. [CrossRef] [PubMed]

37. Juttermann, R.; Li, E.; Jaenisch, R. Toxicity of 5-aza-2'-deoxycytidine to mammalian cells is mediated primarily by covalent trapping of DNA methyltransferase rather than DNA demethylation. Proc. Natl. Acad. Sci. USA 1994, 91, 11797-11801. [CrossRef] [PubMed]

38. Burn, J.E.; Bagnall, D.J.; Metzger, J.D.; Dennis, E.S.; Peacock, W.J. DNA methylation, vernalization, and the initiation of flowering. Proc. Natl. Acad. Sci. USA 1993, 90, 287-291. [CrossRef] [PubMed]

39. Emani, C.; Sunilkumar, G.; Rathore, K.S. Transgene silencing and reactivation in sorghum. Plant Sci. 2002, 162, 181-192. [CrossRef]

40. Van Doorn, W.G.; Beers, E.P.; Dangl, J.L.; Franklin-Tong, V.E.; Gallois, P.; Hara-Nishimura, I.; Jones, A.M.; Kawai-Yamada, M.; Lam, E.; Mundy, J.; et al. Morphological classification of plant cell deaths. Cell Death Differ. 2011, 18, 1241-1246. [CrossRef] [PubMed]

41. Gladish, D.K.; Xu, J.; Niki, T. Apoptosis-like programmed cell death occurs in procambium and ground meristem of pea (Pisum sativum) root tips exposed to sudden flooding. Ann. Bot. 2006, 97, 895-902. [CrossRef] [PubMed]

42. Potten, C.; Wilson, J. Apoptosis: The Life and Death of Cells; Cambridge University Press: Cambridge, UK, 2004. 
43. Bakeeva, L.E.; Dzyubinskaya, E.V.; Samuilov, V.D. Programmed cell death in plants: Ultrastructural changes in pea guard cells. Biochemistry 2005, 70, 972-979. [CrossRef] [PubMed]

44. Gray, J. Programmed Cell Death in Plants; Blackwell Publishing/CRC Press: Oxford, UK; London, UK, 2004.

45. White, E. Life, death, and the pursuit of apoptosis. Genes Dev. 1996, 10, 1-15. [CrossRef] [PubMed]

46. Austin, J.R., 2nd; Frost, E.; Vidi, P.A.; Kessler, F.; Staehelin, L.A. Plastoglobules are lipoprotein subcompartments of the chloroplast that are permanently coupled to thylakoid membranes and contain biosynthetic enzymes. Plant Cell 2006, 18, 1693-1703. [CrossRef] [PubMed]

47. Munne-Bosch, S.; Alegre, L. Die and let live: Leaf senescence contributes to plant survival under drought stress. Funct. Plant Biol. 2004, 31, 203-216. [CrossRef]

48. Sam, O.; Ramirez, C.; Coronado, M.J.; Testillano, P.S.; Risueno, M.C. Changes in tomato leaves induced by $\mathrm{NaCl}$ stress: Leaf organization and cell ultrastructure. Biol. Plant. 2003, 47, 361-366. [CrossRef]

49. Britvec, M.; Reichenauer, T.; Soja, G.; Ljubesic, N.; Eid, M.; Pecina, M. Ultrastructure changes in grapevine chloroplasts caused by increased tropospheric ozone concentrations. Biologia 2001, 56, 417-424.

50. Gadjev, I.; Stone, J.M.; Gechev, T.S. Programmed cell death in plants: New insights into redox regulation and the role of hydrogen peroxide. Int. Rev. Cell Mol. Biol. 2008, 270, 87-144. [PubMed]

51. Vaux, D.L.; Strasser, A. The molecular biology of apoptosis. Proc. Natl. Acad. Sci. USA 1996, 93, $2239-2244$. [CrossRef] [PubMed]

52. Dobrowolska, I.; Kwasniewska, J.; Barlow, P.W.; Kurczynska, E. The fate of surface cell layers of Daucus carota (L.) embryos raised in suspension culture. Plant Biosyst. 2015, 150, 622-630. [CrossRef]

53. Ezaki, B.; Suzuki, M.; Motoda, H.; Kawamura, M.; Nakashima, S.; Matsumoto, H. Mechanism of gene expression of Arabidopsis glutathione S-transferase, AtGST1, and AtGST11 in response to aluminum stress. Plant Physiol. 2004, 134, 1672-1682. [CrossRef] [PubMed]

54. Yang, K.Y.; Kim, Y.; Kim, C.S.; Guh, J.O.; Kim, K.C.; Cho, B.H. Characterization of glutation S-transferase gene AtGST1 in Arabidopsis thaliana. Plant Cell Rep. 1998, 17, 700-704. [CrossRef]

55. Apel, K.; Hirt, H. Reactive oxygen species: Metabolism, oxidative stress, and signal transduction. Annu. Rev Plant Biol. 2004, 55, 373-399. [CrossRef] [PubMed]

56. Gelhaye, E.; Rouhier, N.; Navrot, N.; Jacquot, J.P. The plant thioredoxin system. Cell. Mol. Life Sci. 2005, 62, 24-35. [CrossRef] [PubMed]

57. Wenderoth, I.; Scheibe, R.; von Schaewen, A. Identification of the cysteine residues involved in redox modification of plant plastidic glucose-6-phosphate dehydrogenase. J. Biol. Chem 1997, 272, 26985-26990. [CrossRef] [PubMed]

58. Minina, E.A.; Filonova, L.H.; Fukada, K.; Savenkov, E.I.; Gogvadze, V.; Clapham, D.; Sanchez-Vera, V.; Suarez, M.F.; Zhivotovsky, B.; Daniel, G.; et al. Autophagy and metacaspase determine the mode of cell death in plants. J. Cell Biol. 2013, 203, 917-927. [CrossRef] [PubMed]

59. Kim, C.; Meskauskiene, R.; Zhang, S.; Lee, K.P.; Lakshmanan Ashok, M.; Blajecka, K.; Herrfurth, C.; Feussner, I.; Apel, K. Chloroplasts of Arabidopsis are the source and a primary target of a plant-specific programmed cell death signaling pathway. Plant Cell 2012, 24, 3026-3039. [CrossRef] [PubMed]

60. Shi, H.; Kim, Y.; Guo, Y.; Stevenson, B.; Zhu, J.K. The Arabidopsis SOS5 locus encodes a putative cell surface adhesion protein and is required for normal cell expansion. Plant Cell 2003, 15, 19-32. [CrossRef] [PubMed]

61. Xu, C.; Takac, T.; Burbach, C.; Menzel, D.; Samaj, J. Developmental localization and the role of hydroxyproline rich glycoproteins during somatic embryogenesis of banana (Musa spp. AAA). BMC Plant Biol. 2011, 11, 38. [CrossRef] [PubMed]

62. Egertsdotter, U.; von Arnold, S. Importance of arabinogalactan proteins for the development of somatic embryos of Picea abies. Physiol. Plant. 1995, 93, 334-345. [CrossRef]

63. Chapman, A.; Blervacq, A.S.; Vasseur, J.; Hilbert, J.L. Arabinogalactan-proteins in Cichorium somatic embryogenesis: Effect of beta-glucosyl Yariv reagent and epitope localisation during embryo development. Planta 2000, 211, 305-314. [CrossRef] [PubMed]

64. Rodriguez-Furlan, C.; Salinas-Grenet, H.; Sandoval, O.; Recabarren, C.; Arrano-Salinas, P.; Soto-Alvear, S.; Orellana, A.; Blanco-Herrera, F. The root hair specific SYP123 regulates the localization of cell wall components and contributes to rizhobacterial priming of induced systemic resistance. Front. Plant Sci. 2016, 7, 1081. [CrossRef] [PubMed]

65. Coimbra, S.; Almeida, J.; Junqueira, V.; Costa, M.L.; Pereira, L.G. Arabinogalactan proteins as molecular markers in Arabidopsis thaliana sexual reproduction. J. Exp. Bot. 2007, 58, 4027-4035. [CrossRef] [PubMed] 
66. Schindler, T.; Bergfeld, R.; Schopfer, P. Arabinogalactan proteins in maize coleoptiles: Developmental relationship to cell death during xylem differentiation but not to extension growth. Plant J. 1995, 7, 25-36. [CrossRef] [PubMed]

67. García-Angulo, P.; Willats, W.G.T.; Encina, A.E.; Alonso-Simon, A.; Alvarez, J.M.; Acebes, J.L. Immunocytochemical characterization of the cell walls of bean cell suspensions during habituation and dehabituation to dichlobenil. Physiol. Plant. 2006, 127, 87-99. [CrossRef]

68. Kawanabe, T.; Ariizumi, T.; Kawai-Yamada, M.; Uchimiya, H.; Toriyama, K. Abolition of the tapetum suicide program ruins microsporogenesis. Plant Cell Physiol. 2006, 47, 784-787. [CrossRef] [PubMed]

69. Cannon, M.C.; Terneus, K.; Hall, Q.; Tan, L.; Wang, Y.; Wegenhart, B.L.; Chen, L.; Lamport, D.T.; Chen, Y.; Kieliszewski, M.J. Self-assembly of the plant cell wall requires an extensin scaffold. Proc. Natl. Acad. Sci. USA 2008, 105, 2226-2231. [CrossRef] [PubMed]

70. Steedman, H.F. Polyester wax; a new ribboning embedding medium for histology. Nature 1957, $179,1345$. [CrossRef] [PubMed]

71. Wolny, E.; Braszewska-Zalewska, A.; Hasterok, R. Spatial distribution of epigenetic modifications in Brachypodium distachyon embryos during seed maturation and germination. PLoS ONE 2014, 9, e101246. [CrossRef] [PubMed]

72. Kwasniewska, J.; Kus, A.; Swoboda, M.; Braszewska-Zalewska, A. DNA replication after mutagenic treatment in Hordeum vulgare. Mutat. Res. 2016, 812, 20-28. [CrossRef] [PubMed]

73. Mornkham, T.; Wangsomnuk, P.P.; Fu, Y.B.; Wangsomnuk, P.; Jogloy, S.; Patanothai, A. Extractions of high quality RNA from the seeds of Jerusalem artichoke and other plant species with high levels of starch and lipid. Plants 2013, 2, 302-316. [CrossRef] [PubMed]

74. Pennell, R.I.; Janniche, L.; Kjellbom, P.; Scofield, G.N.; Peart, J.M.; Roberts, K. Developmental regulation of a plasma membrane arabinogalactan protein epitope in oilseed rape flowers. Plant Cell 1991, 3, 1317-1326. [CrossRef] [PubMed]

75. Knox, J.P.; Linstead, P.J.; Peart, J.; Cooper, C.; Roberts, K. Developmentally regulated epitopes of cell surface arabinogalactan proteins and their relation to root tissue pattern formation. Plant J. 1991, 1, 317-326. [CrossRef] [PubMed]

76. Smallwood, M.; Martin, H.; Knox, J.P. An epitope of rice threonine-rich and hydroxyproline-rich glycoprotein is common to cell-wall and hydrophobic plasma-membrane glycoproteins. Planta 1995, 196, 510-522. [CrossRef] [PubMed]

77. Smallwood, M.; Beven, A.; Donovan, N.; Neill, S.J.; Peart, J.; Roberts, K.; Knox, J.P. Localization of cell wall proteins in relation to the developmental anatomy of the carrot root apex. Plant J. 1994, 5, 237-246. [CrossRef] 